\title{
Combined stomach content, lipid and stable isotope analyses reveal spatial and trophic partitioning among three sympatric albatrosses from the Southern Ocean
}

\author{
Maëlle Connan ${ }^{1,2,7, *}$, Christopher D. McQuaid ${ }^{1}$, Bo T. Bonnevie ${ }^{3}$, \\ Malcolm J. Smale ${ }^{4,5}$, Yves Cherel ${ }^{6}$
}

\author{
${ }^{1}$ Rhodes University, Department of Zoology and Entomology, PO Box 94, Grahamstown 6140, South Africa \\ ${ }^{2}$ Percy FitzPatrick Institute of Africa Ornithology, DST/NRF Centre of Excellence, University of Cape Town, \\ Rondebosch 7701, South Africa \\ ${ }^{3}$ Rhodes University, Information Technology Division, PO Box 94, Grahamstown 6140, South Africa \\ ${ }^{4}$ Port Elizabeth Museum at Bayworld, PO Box 13147, Humewood 6013, South Africa \\ ${ }^{5}$ Zoology Department, Nelson Mandela Metropolitan University, PO Box 77000, Port Elizabeth 6031, South Africa \\ ${ }^{6}$ Centre d'Etudes Biologiques de Chizé, Centre National de la Recherche Scientifique, Villiers-en-Bois, \\ 79360 Beauvoir-sur-Niort, France
}

${ }^{7}$ Present address: Zoology Department, Nelson Mandela Metropolitan University, PO Box 77000, Port Elizabeth 6031 South Africa

\begin{abstract}
A combination of dietary techniques that integrate data on food and feeding habits over days, weeks and months was used to investigate resource partitioning among 3 sympatric albatrosses, namely the grey-headed Thalassarche chrysostoma (GHA), light-mantled sooty Phoebetria palpebrata (LMSA) and sooty Phoebetria fusca (SA) albatrosses. These medium-size albatrosses typically breed every $2 \mathrm{yr}$, and Marion Island (southern Indian Ocean) is the only breeding site where the 3 species are accessible. Stomach content analysis provided dietary information about the most recent meal, analysis of fatty acids in stomach oils about the last foraging trip, and carbon and nitrogen stable isotope values of blood and feathers about the chick-rearing (breeding) and moulting periods, respectively. The combination of techniques highlighted a complex pattern regarding the spatial and trophic segregation between the 3 species. During both seasons, SA were spatially segregated from LMSA and GHA, foraging farther north (in subantarctic and subtropical areas) than the 2 other species (subantarctic and Antarctic waters). When feeding for themselves during the breeding season (blood isotopic signatures), adults showed a clear spatial segregation. When bringing back food for their chicks (stomach contents), trophic segregation became obvious, with the 2 Phoebetria species specializing mostly on squids. The results illustrate how sympatrically breeding birds can show niche partitioning through both spatial segregation and prey specialization.
\end{abstract}

KEY WORDS: Phoebetria palpebrata Phoebetria fusca $\cdot$ Thalassarche chrysostoma $\cdot$ Trophic segregation $\cdot$ Spatial segregation $\cdot$ Moulting period $\cdot$ Breeding season

Resale or republication not permitted without written consent of the publisher

\section{INTRODUCTION}

Like all seabirds, albatrosses have evolved from terrestrial origins and, although now highly specialized to forage at sea, they are wholly dependent on land to breed. In the Southern Hemisphere, the oceans are vast compared with available breeding space, and the nesting grounds of seabirds are therefore typically characterized by important species diversity and very high nesting densities. This results 
in increased foraging pressures on marine resources in the vicinity of the breeding grounds at precisely the time when energetic requirements are greatest due to breeding.

Subantarctic Marion Island hosts at least 25 species of seabirds, including 4 species of albatrosses, namely the wandering Diomedea exulans, grey-headed Thalassarche chrysostoma (GHA), sooty Phoebetria fusca (SA) and light-mantled sooty Phoebetria palpebrata (LMSA) albatrosses (Ryan \& Bester 2008). These 4 species are biennial breeders, but unlike the wandering albatross, which has a breeding season lasting $\sim 1 \mathrm{yr}$, the 3 medium-size albatrosses breed in summer, returning to colonies in August and September, and fledging chicks in May and June (Ryan \& Bester 2008). While seabirds are restricted to their breeding sites during the breeding season, individuals are able to increase their foraging range during the nonbreeding season.

Many methods are used to study seabird diets, and the combination of techniques with different temporal resolutions allows dietary investigations across varying time scales (Karnovsky et al. 2012). Conventional stomach content analysis (i.e. identification of prey remains) provides information about the most recent meals of an individual. Procellariiform species are unique in that most of them are able to store oil of dietary origin in their proventriculus (Warham et al. 1976) and the fatty acid signatures of these stomach oils provide dietary information about the last foraging trip (Connan et al. 2005, 2007). Carbon $\left(\delta^{13} \mathrm{C}\right)$ and nitrogen $\left(\delta^{15} \mathrm{~N}\right)$ stable isotope ratios have been used as indicators of foraging areas and trophic level, respectively (e.g. Hobson \& Clark 1992). Avian whole blood has a rapid turnover and represents the diet integrated over a period of a few weeks prior to sampling, and for birds sampled during the breeding season, this will give information about the diet during that period (Hobson \& Clark 1992). The full complement of adult body feathers are replaced gradually over the whole interbreeding period (Warham 1996), with a body feather of 6 to $10 \mathrm{~cm}$ typically taking about 2 to 3 wk to grow (Jaeger et al. 2010a). Feathers remain isotopically inert once fully grown (Mizutani et al. 1990). $\delta^{13} \mathrm{C}$ shows well-defined latitudinal isoscapes within the Southern Ocean, decreasing towards higher latitudes (e.g. Cherel \& Hobson 2007, Jaeger et al. 2010b). Foraging during the interbreeding period of albatrosses can thus be examined through the stable isotope carbon signatures of their feathers (Phillips et al. 2009, Cherel et al. 2013).

Given the constraints on breeding sites, resource overlap between land-breeding marine predators might be enhanced during the breeding season and relaxed during the non-breeding season. In an environment with limited resources, this overlap may result in competition, and it is then reasonable to assume that (1) sympatric species will be more likely to show trophic segregation during the breeding season (Croxall et al. 1999), and (2) each species will return to its preferred foraging areas outside the breeding season. On the other hand, if there were unlimited resources, competition would not be expected, and, therefore, neither would dietary segregation. The aim of the present work was to study resource partitioning within the community of medium-size albatrosses (GHA, SA and LMSA) at Marion Island to estimate the degree of dietary overlap and trophic segregation during the breeding and moulting seasons using a combination of stomach content analysis, with lipids and stable isotopes as trophic markers (Karnovsky et al. 2008, 2012, Connan et al. 2010b).

\section{MATERIALS AND METHODS}

\section{Study site and species}

Fieldwork was carried out on Marion Island (Prince Edward Islands; $\left.46^{\circ} 52^{\prime} \mathrm{S}, 37^{\circ} 51^{\prime} \mathrm{E}\right)$. The island lies in the subantarctic zone sensu lato of the Southern Ocean, between the Subtropical Front to the north and the Antarctic Polar Front to the south (Lutjeharms \& Ansorge 2008; Fig. 1). Marion Island supports $11 \%$ of the world's population of SA (1400 breeding pairs), $8 \%$ of its GHA population (7500 breeding pairs), and $3 \%$ of its LMSA population (600 breeding pairs; Ryan et al. 2009), and, with the Crozet Islands, is one of only 2 places where both species of sooty albatrosses (SA and LMSA) breed in substantial numbers. Breeding sites of GHA are restricted to the south coast of Marion Island, while SA and LMSA nest on cliffs around the island perimeter, as well as on inland cliffs in the case of LMSA. The 3 species are of similar size with a wing span around 1.8 to $2.2 \mathrm{~m}$ (Harrison 1983), and their masses range from $2.5 \mathrm{~kg}$ for SA to $3.6 \mathrm{~kg}$ for GHA (Hockey et al. 2005).

\section{Sampling}

Samples were collected in April and May 2009 from breeding adults and chicks of the 3 species. Field identification of SA and LMSA chicks was possible using the size and the colour of the ring of 


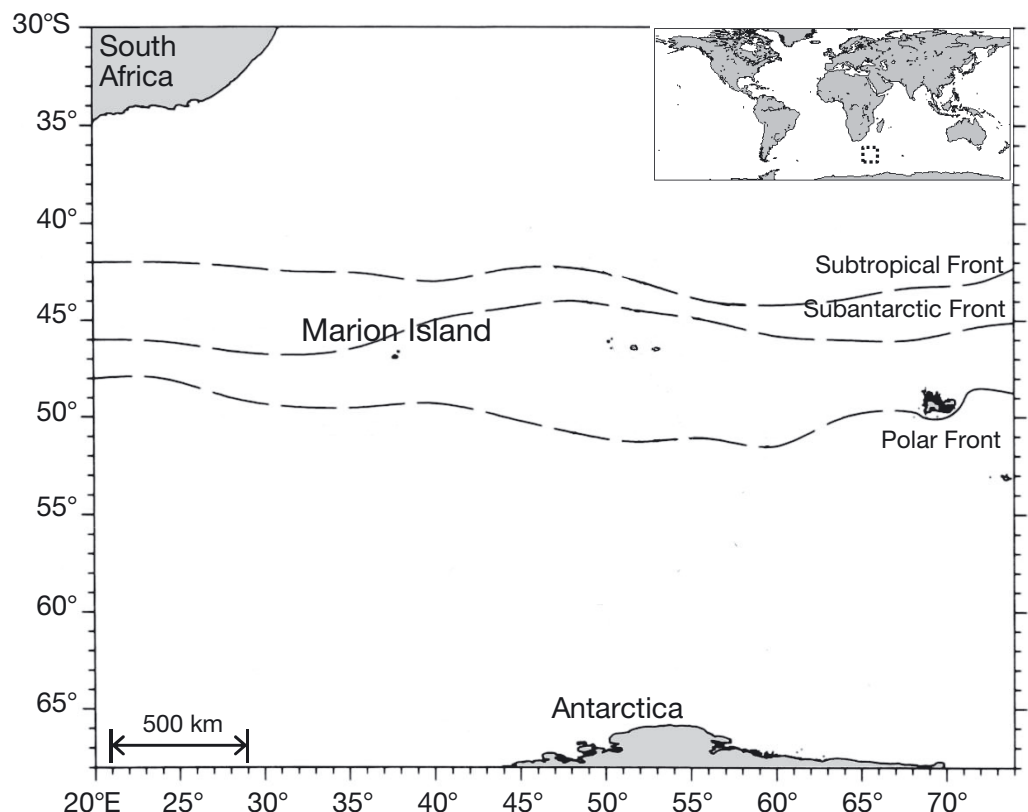

Fig. 1. Location of Marion Island in the southwestern Indian Ocean. Front positions follow Park et al. (1993)

feathers immediately posterior to the eye; molecular identification was used to confirm borderline cases (Connan et al. 2011).

The prey brought back by the adults during the chick-rearing period is destined for their chicks; consequently no distinction was made between the stomach contents of the 2 age classes. Stomach contents were collected when either adults or chicks regurgitated spontaneously during handling or after gentle stomach massage. Stomach oils were separated from the prey remains when present and immediately placed in $2 \mathrm{ml}$ chloroform with $0.01 \%$ butylated-hydroxytoluene in a nitrogen-saturated atmosphere to avoid lipid oxidation. Both stomach contents and oils were then stored at $-20^{\circ} \mathrm{C}$ until subsequent analyses. For each bird, a blood sample was taken from the tarsus vein and preserved in $70 \%$ ethanol for subsequent stable isotope (adults) or genetic analysis (chicks). Preservation in $70 \%$ ethanol does not significantly change the stable carbon or nitrogen isotope ratios of samples (Hobson et al. 1997). Four feathers were removed from the back of each bird's neck and stored in plastic bags for subsequent processing.

\section{Laboratory analyses}

Stomach contents. Each stomach content was thawed and drained by gravity overnight to separate the solid items from the residual liquid fraction. Fresh remains were separated from accumulated items (mainly squid beaks with no flesh attached), and divided into broad prey classes (cephalopods, crustaceans, fish and carrion) that were weighed to estimate their proportion by wet mass in the diet. Then, prey items (fresh and accumulated) were counted and identified to the lowest possible taxon, using published keys and our own reference collection. For accumulated squid beaks, all lower and upper beaks were identified (Xavier et al. 2011). In addition, the lower rostral length of beaks was measured to $0.1 \mathrm{~mm}$ with Vernier callipers and allometric equations were used to estimate squid mantle length (see Xavier \& Cherel 2009).

Lipids. Since lipid composition of stomach oils is similar for adults and chicks (Connan et al. 2007), no age distinction was made in the present study. Total lipids of stomach oils were extracted following Allan et al. (2010). Lipid classes were then isolated by preparative thin-layer chromatography, and bands of wax esters, triacylglycerols and diacylglycerol ethers were scraped off, eluted and the 3 lipid classes weighed; stomach oils are typically rich in neutral lipids (Warham et al. 1976, Connan et al. 2007). Fatty acid methyl esters were prepared from triacylglycerol fractions using methods detailed in Allan et al. (2010). The fatty acid methyl ester composition of each sample was determined by gas chromatography analysis using an Agilent Technologies 7890A gas chromatographic System with a ZB-Waxplus 320 column $(30 \mathrm{~m}$ length, $0.25 \mathrm{~mm}$ internal diameter, $0.25 \mu \mathrm{m}$ film thickness; Zebron Corporation) with helium as the carrier gas. The injection temperature was $250^{\circ} \mathrm{C}$, the flame ionization detector was set at $260^{\circ} \mathrm{C}$, and the oven was initially set at $150^{\circ} \mathrm{C}$. After $5 \mathrm{~min}$, the oven temperature was raised to $225^{\circ} \mathrm{C}$ at a rate of $2.5^{\circ} \mathrm{C} \mathrm{min}{ }^{-1}$ and held for $9 \mathrm{~min}$. Peaks were integrated using GC ChemStation software (Agilent Technologies, version B.04.02), identified by comparison with retention times of external standards (37 component fatty acid methyl ester mix Supelco, marine PUFA no. 1 Supelco, bacterial acid methyl esters mix Supelco), as well as by mass spectrometry analysis (Agilent Technologies 7000 GC/MS Triple Quad; Agilent MassHunter Qualitative Analysis, version B.03.01). 
Each fatty acid was measured as a proportion of the total array of fatty acids detected (\% TFAs).

Stable isotopes. Four feathers per bird were individually cleaned in a 2:1 chloroform:methanol solution placed in an ultrasonic bath for $2 \mathrm{~min}$, rinsed in successive baths of methanol and deionised water, and then dried $\left(50^{\circ} \mathrm{C}, 24 \mathrm{~h}\right)$. Each whole body feather was homogenised by fine cutting with stainless steel scissors. Whole blood samples were dried at $50^{\circ} \mathrm{C}$ for $24 \mathrm{~h}$ and finely ground to a homogenous powder. Typically, avian whole blood does not require lipid extraction (Cherel et al. 2005). The relative isotopic abundances of carbon $\left({ }^{13} \mathrm{C} /{ }^{12} \mathrm{C}\right)$ and nitrogen $\left({ }^{15} \mathrm{~N} /{ }^{14} \mathrm{~N}\right)$ were determined on 0.5 to $0.6 \mathrm{mg}$ subsamples of materials with a Thermo Finnigan Delta XP Plus mass spectrometer interfaced with a Conflo III device to a Thermo Flash EA 1112 elemental analyzer (Stable Light Isotope Unit, University of Cape Town, South Africa). Results are presented in the usual $\delta$ notation relative to Vienna PeeDee Belemnite and atmospheric $\mathrm{N}_{2}$ for $\delta^{13} \mathrm{C}$ and $\delta^{15} \mathrm{~N}$, respectively. Replicate measurements of internal laboratory standards indicate measurement errors $<0.08 \%$ and $<0.12 \%$ for stable carbon and nitrogen isotope measurements, respectively.

\section{Data analyses and statistics}

A combination of univariate and multivariate analyses was used to evaluate resource overlap between species. When datasets did not meet the required assumptions of normality (Shapiro-Wilk test) and/or homogeneity of variances (Fisher's test), nonparametrical tests were used. Multiple comparison post-hoc tests were performed in cases of significant differences.

For stomach content analysis, the importance of each prey taxon was described by its frequency of occurrence and numerical abundance. Frequency of occurrence was expressed as a percentage of the number of food samples containing a given taxon. Numerical importance was calculated as the total number of individuals of a given taxon found in all the samples as a percentage of the total number of all prey items ingested in all the food samples.

Variability in the triacylglycerol fatty acid composition of stomach oils was first investigated using an analysis of similarities (ANOSIM) with the BrayCurtis distance measure and assessed with the global R-value; large positive R (up to 1) signifies dissimilarity between groups (Hammer et al. 2001). Non-metric multidimensional scaling was used to visualize dif- ferences between species; relationships between samples were considered well represented when stress was $<0.2$. An attempt at identifying the prey from which triacylglycerols in oils originated was then made using a quantitative analysis (Iverson et al. 2004; see details in Connan et al. 2010a). Briefly, the proportional contribution of a prey species to the oil composition was determined by taking a weighted mixture of the fatty acid signatures of potential prey species and then choosing weighting that minimised the statistical distance from that of albatrosses (Iverson et al. 2004). The best fit was evaluated with the category 'unknown species', referring to the part of the diet that could not be explained by any potential prey in our data set. Ideally, potential prey and predators should be collected simultaneously to reduce spatial and/or temporal variability as much as possible. However, when working with albatrosses that can travel thousands of kilometres over the open ocean, such ideal sampling is unrealistic. Our prey database thus included the fatty acid signatures of 44 prey species gathered from the literature (4 crustacean, 27 fish and 13 cephalopod species; see Table S1 in the Supplement at www. int-res.com/articles/suppl/m497p259_supp.pdf for a complete species list and references) described by 24 fatty acids.

For stable isotopes, the analysis of individual feathers from adult birds allowed us to derive 3 parameters: the total niche width (TNW), estimated as the variance among all feathers of a given species, and the within-individual (WIC) and the betweenindividual (BIC) components. The WIC is the average variance of 4 individual feathers, and the BIC is the variation among means of 4 individual feathers (Bolnick et al. 2002). These indices were calculated using a generalized linear mixed model because the data were nested. In addition, bivariate ellipses were used to plot isotopic niches of the 3 albatross species. As feather isotopic data strongly failed the multivariate normality assumption, they were centred and rescaled before using the Stable Isotope Bayesian Ellipses in R (SIBER) package (Jackson et al. 2011). The following metrics were then estimated: standard ellipse area corrected for small sample size (less dependent over sample size than convex hull area), bayesian standard ellipse areas, which overlaps the corrected standard ellipse area, and differences in standard ellipse area (Jackson et al. 2011). We acknowledge the uncertainty associated with small sample sizes in these estimates (Syväranta et al. 2013). Finally, albatross isotopic ratios of carbon and nitrogen were compared with isoscape values for the 
Polar and Subtropical fronts (Cherel \& Hobson 2007, Jaeger et al. 2010b).

All statistical analyses were performed using R statistical Software (R Development Core Team 2009) and PAST (Hammer et al. 2001).

\section{RESULTS}

\section{Stomach contents}

Stomach contents were collected from 39 birds (19 GHA, 10 LMSA, 10 SA), with 20 of them containing oil (51\% of stomach contents). Food samples of LMSA and SA were dominated by squid remains (77 and $78 \%$ by fresh mass, respectively-squid remains dominated in 8 out of 10 LMSA samples and 7 out of 10 SA samples), whereas GHA food samples were mostly composed of a mix of fish and squid ( $46 \%$ and $36 \%$ by fresh mass, respectively - fish and squid remains dominated in 11 and 5 out of 19 contents, respectively; Fig. 2). Carrion was found in 3 stomach contents (1 GHA, 1 LMSA, 1 SA), with the stomach content of 1 LMSA being entirely composed of penguin remains. A total of 1905 prey items were recovered in samples from the 3 albatross species (Table 1). The digested state of many items precluded their identification to species level. Crustaceans formed a small part by mass for the 3 species $(15 \%, 2 \%$ and $3 \%$ of fresh items for GHA, LMSA and $\mathrm{SA}$, respectively), but dominated by number. Fiftyseven percent of the prey items were the subantarctic krill Euphausia vallentini, recovered from 1 SA sample, followed by the Antarctic krill Euphausia superba $(27 \%)$ and the amphipod Themisto gaudichaudii (7\%) Antarctic krill were recovered in $20 \%$ of LMSA samples and $11 \%$ of GHA samples, but never in SA samples. Most of the fish remains could not be identified to species level because otoliths were too eroded. The fish family Macrouridae was the most abundant followed by Gempylidae in GHA stomach contents. Although cephalopods dominated by fresh mass, only 4 species could be identified from intact buccal masses: Kondakovia longimana, Histioteuthis eltaninae, Alluroteuthis antarcticus and Batoteuthis skolops (Table 1).

Accumulated squid beaks were found in $58 \%, 60 \%$ and $70 \%$ of the GHA, LMSA and SA stomach contents, respectively. The 3 species Histioteuthis eltaninae, Galiteuthis glacialis and Kondakovia longimana were the most abundant cephalopod prey for all 3 albatross species (Table 2). K. longimana was the most abundant species in GHA samples, and $H$. eltaninae in LMSA and SA samples. Estimated sizes of cephalopods ranged from Mastigoteuthis sp. A (Clarke) with an estimated mantle length of $5.7 \mathrm{~cm}$ to an individual of $K$. longimana with a mantle length of $60.5 \mathrm{~cm}$. For the latter species, estimated mantle lengths in GHA stomachs were all between 20.6 and $39.9 \mathrm{~cm}$, however $75 \%$ of $K$. longimana beaks found in GHA stomachs came from juveniles and could not be measured because they were too eroded.

\section{Fatty acids}

Triacyglycerols and wax esters were recovered in all 20 stomach oil samples (9 each from GHA and LMSA, 2 from SA), while diacylglycerol ethers were found in only $30 \%$ of the oils (11\% of GHA, $44 \%$ of LMSA and $50 \%$ of SA samples) (Fig. 3).

Twenty-one fatty acids were detected at $>0.5 \%$ of TFAs in the triacylglycerol fractions (Table 3). Half of the fatty acids were monounsaturated with oleic acid (18:1(n-9)) being dominant, followed by palmitic acid (16:0) and eicosapentaenoic acid (20:5(n-3)). Overall, differences in the fatty acid compositions between the 3 albatross species were marginally non-significant (ANOSIM: global $\mathrm{R}=0.157, \mathrm{p}=0.053$ ). This result was confirmed with a non-metric multidimensional scaling plot analysis (data not shown; 2 D stress value $=0.14$ ) .

The optimisation model estimates were variable between individuals and no clear distinction could be made among the 3 albatross species (ANOSIM:

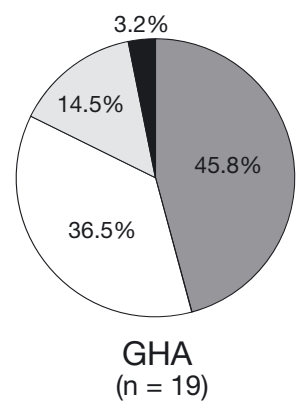

(n = 19)

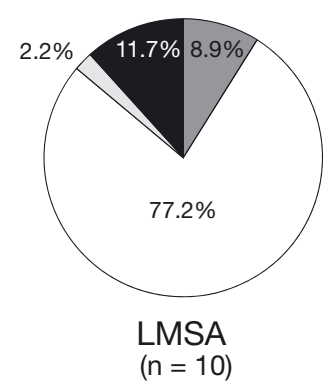

$(n=10)$

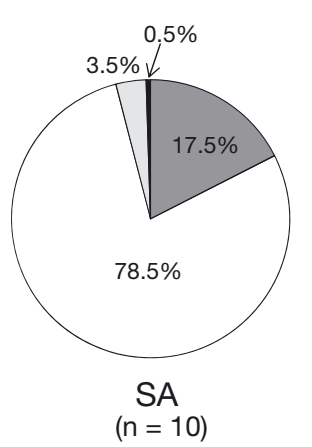

$(\mathrm{n}=10)$

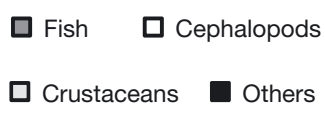

Fig. 2. Broad prey class composition (\% by fresh mass) of the stomach contents for the 3 albatross species (grey-headed [GHA], lightmantled sooty [LMSA] and sooty [SA] albatrosses) 
Table 1. Frequency of occurrence (\% of stomach contents) and number of prey items (\% of total number of prey items) recovered in the fresh fraction of stomach contents in the 3 albatross species (grey-headed [GHA], light-mantled sooty [LMSA] and sooty [SA] albatrosses)

\begin{tabular}{|c|c|c|c|c|c|c|c|c|c|c|c|c|}
\hline & \multicolumn{4}{|c|}{$\longrightarrow$ GHA $(n=19)-$} & \multicolumn{4}{|c|}{$\longrightarrow$ LMSA $(n=10)-$} & \multicolumn{4}{|c|}{$\longrightarrow$ SA $(n=10)$} \\
\hline & \multirow{2}{*}{\multicolumn{2}{|c|}{$\begin{array}{c}\text { Occurrence } \\
\mathrm{N} \quad(\%)\end{array}$}} & \multicolumn{2}{|c|}{ Number } & \multicolumn{2}{|c|}{ Occurrence } & \multicolumn{2}{|c|}{ Number } & \multicolumn{2}{|c|}{ Occurrence } & \multicolumn{2}{|c|}{ Number } \\
\hline & & & $\mathrm{N}$ & $(\%)$ & $\mathrm{N}$ & $(\%)$ & $\mathrm{N}$ & $(\%)$ & $\mathrm{N}$ & $(\%)$ & $\mathrm{N}$ & $(\%)$ \\
\hline \multicolumn{13}{|l|}{ Crustaceans } \\
\hline \multicolumn{13}{|l|}{ Amphipoda } \\
\hline \multicolumn{13}{|l|}{ Eurytheneidae } \\
\hline Eurythenes obesus & 1 & (5) & 1 & $(0.1)$ & 1 & $(10)$ & 1 & $(1.6)$ & & & & \\
\hline Gammaridea sp. & 1 & (5) & 1 & $(0.1)$ & & & & & & & & \\
\hline \multicolumn{13}{|l|}{ Hyperiidae } \\
\hline Hyperiella antarctica & 1 & (5) & 2 & $(0.3)$ & & & & & & & & \\
\hline Themisto gaudichaudii & 7 & $(37)$ & 122 & $(16.6)$ & 1 & $(10)$ & 1 & $(1.6)$ & 2 & $(20)$ & 7 & $(0.6)$ \\
\hline \multicolumn{13}{|l|}{ Vibiliidae } \\
\hline Cyllopus magellanicus & 1 & (5) & 1 & $(0.1)$ & & & & & & & & \\
\hline \multicolumn{13}{|l|}{ Cirripedia } \\
\hline Lepas australis (cypris larvae) & 3 & $(16)$ & 10 & $(1.4)$ & & & & & & & & \\
\hline Lepas sp. & 7 & (37) & 11 & (1.5) & & & & & & & & \\
\hline \multicolumn{13}{|l|}{ Decapoda } \\
\hline Pasiphaea scotiae & 1 & (5) & 2 & $(0.3)$ & 1 & $(10)$ & 1 & $(1.6)$ & & & & \\
\hline Euphausiacea & & & & & & & & & & & & \\
\hline Euphausia superba & 2 & (11) & 474 & $(64.4)$ & 2 & $(20)$ & 46 & $(73.0)$ & & & & \\
\hline Euphausia vallentini & 1 & (5) & 8 & (1.1) & & & & & 1 & (10) & 1081 & $(97.7)$ \\
\hline Euphausia sp. & 7 & $(37)$ & 45 & $(6.1)$ & 3 & (30) & 3 & $(4.8)$ & 1 & (10) & 7 & $(0.6)$ \\
\hline Mysida & & & & & & & & & & & & \\
\hline Neognathophausia gigas & 1 & (5) & 1 & $(0.1)$ & & & & & 1 & (10) & 1 & $(0.1)$ \\
\hline Unidentified Isopoda & 1 & (5) & 1 & $(0.1)$ & & & & & & & & \\
\hline Unidentified crustacean & 3 & $(16)$ & 4 & $(0.5)$ & 1 & $(10)$ & 1 & $(1.6)$ & & & & \\
\hline Gastropoda & & & & & & & & & & & & \\
\hline Clione sp. & 5 & $(26)$ & 26 & $(3.5)$ & & & & & & & & \\
\hline Fish & & & & & & & & & & & & \\
\hline Phosichthyidae & & & & & & & & & & & & \\
\hline Phosichthys argenteus & 1 & (5) & 1 & $(0.1)$ & & & & & & & & \\
\hline Myctophidae & & & & & & & & & & & & \\
\hline Gymnoscopelus piabilis & & & & & & & & & 1 & (10) & 1 & $(0.1)$ \\
\hline Moridae & & & & & & & & & & & & \\
\hline Antimora rostrata & & & & & & & & & 1 & (10) & 1 & $(0.1)$ \\
\hline Macrouridae & & & & & & & & & & & & \\
\hline ?Coryphaenoides armatus & 2 & (11) & 3 & $(0.4)$ & & & & & & & & \\
\hline Gempylidae & & & & & & & & & & & & \\
\hline Paradiplospinus gracilis & 2 & (11) & 2 & $(0.3)$ & & & & & & & & \\
\hline Unidentified fish & 10 & (53) & 13 & $(1.8)$ & 5 & $(50)$ & 5 & $(7.9)$ & 1 & $(10)$ & 1 & $(0.1)$ \\
\hline Cephalopods & & & & & & & & & & & & \\
\hline Onychoteuthidae & & & & & & & & & & & & \\
\hline Kondakovia longimana & & & & & & & & & 1 & (10) & 1 & $(0.1)$ \\
\hline Histioteuthidae & & & & & & & & & & & & \\
\hline Histioteuthis eltaninae & 1 & $(5)$ & 1 & $(0.1)$ & 1 & $(10)$ & 1 & $(1.6)$ & 2 & $(20)$ & 3 & $(0.3)$ \\
\hline Neoteuthidae & & & & & & & & & & & & \\
\hline Alluroteuthis antarcticus & & & & & 1 & (10) & 1 & $(1.6)$ & & & & \\
\hline Batoteuthidae & & & & & & & & & & & & \\
\hline Batoteuthis skolops & 1 & (5) & 1 & $(0.1)$ & & & & & & & & \\
\hline Unidentified squid & 6 & $(32)$ & 6 & $(0.8)$ & 3 & $(30)$ & 3 & $(4.8)$ & 3 & $(30)$ & 3 & $(0.3)$ \\
\hline Others & & & & & & & & & & & & \\
\hline Carrion & 1 & (5) & & & 1 & $(10)$ & & & 1 & (10) & & \\
\hline
\end{tabular}

global $\mathrm{R}=0.024, \mathrm{p}=0.346)$. This result was confirmed with a non-metric multidimensional scaling plot analysis (data not shown; 2D stress value $=0.04$ ). Overall, triacylglycerol fatty acids originated from fish species for $90 \%$ of the oils followed by cephalo- pods and crustaceans (Fig. 4). When looking at prey species, the fish Champsocephalus gunnari and Coryphaenoides armatus, the cephalopod Gonatus antarcticus and the crustacean Euphausia superba were found to be the main prey of the albatrosses. 


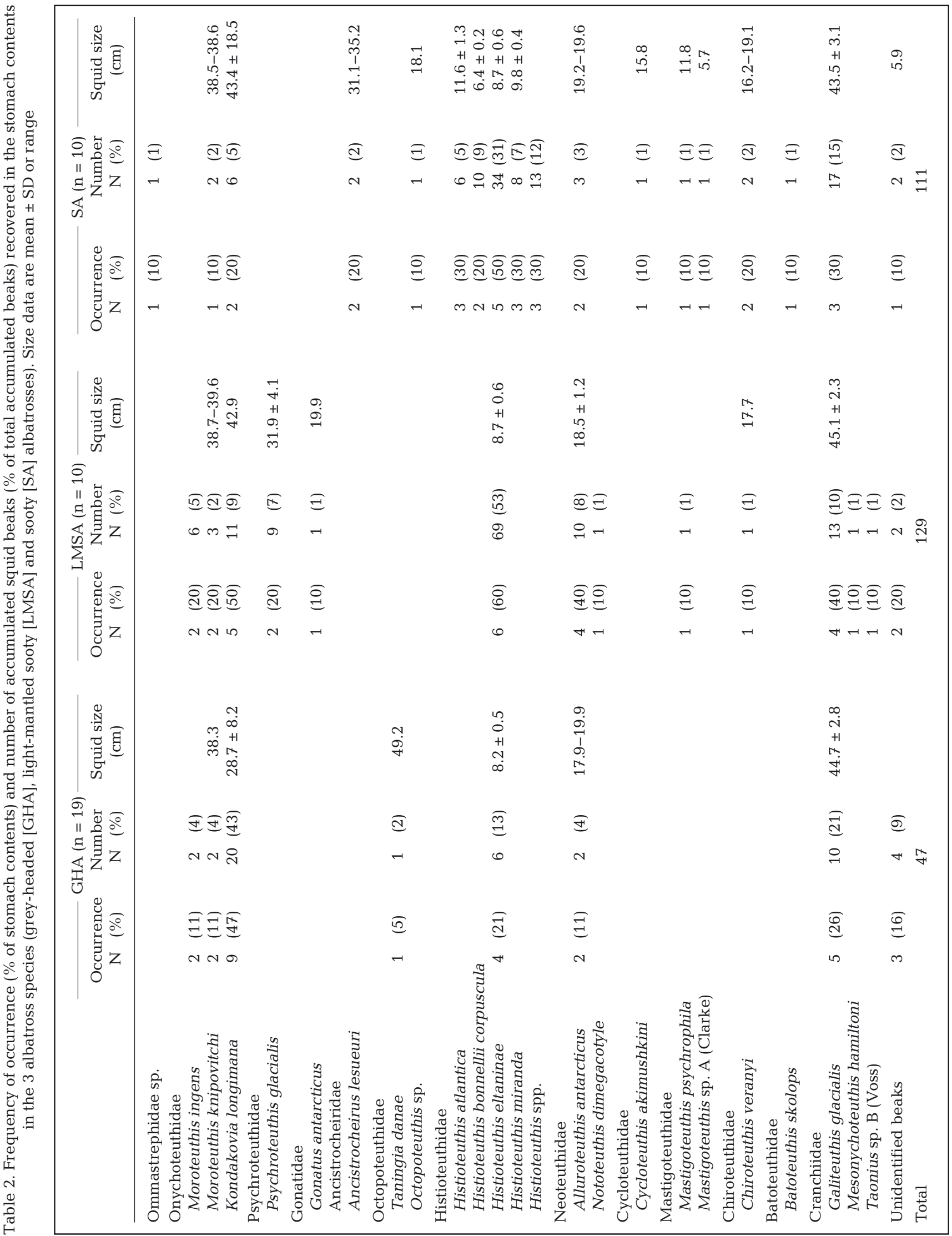




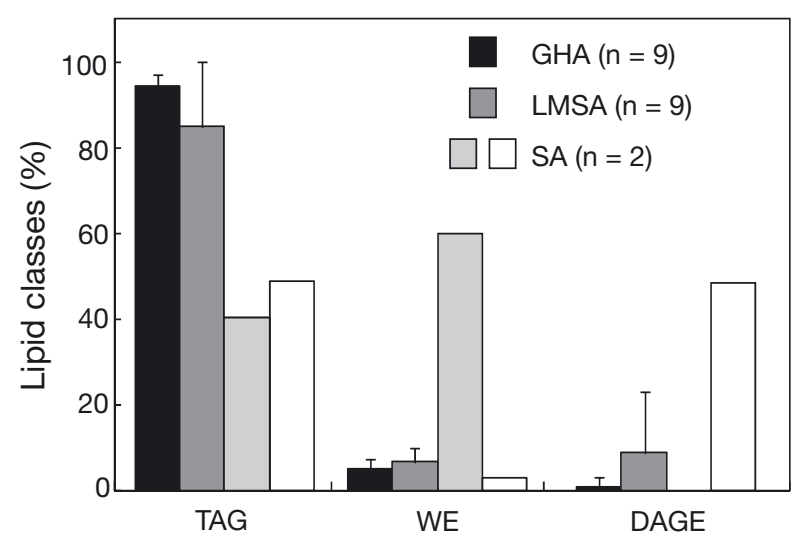

Fig. 3. Neutral lipid class composition of stomach oils (triacylglycerols [TAG], wax esters [WE] and diacylglycerol ethers [DAGE]) of the 3 albatross species (grey-headed [GHA; black], light-mantled sooty [LMSA; dark-grey] and sooty $\left[\mathrm{SA}_{i}\right.$ light grey and white for samples a and b, respectively] albatrosses)

\section{Stable isotopes}

During the breeding season, blood $\delta^{13} \mathrm{C}$ values were higher in SA than in GHA and LMSA $(\mathrm{H}=28.2$, $\mathrm{p}<0.001$, SA $>$ GHA = LMSA; Table 4, Fig. 5) and blood $\delta^{15} \mathrm{~N}$ values were lower in GHA than in SA $(\mathrm{H}=$ 26.7, p $<0.001, \mathrm{SA} \geq \mathrm{LMSA}=$ GHA; Table 4, Fig. 5A). This result was illustrated by the corrected standard ellipse areas for the 3 albatross species that differed in size, shape and position (Fig. 6A). GHA had the smallest corrected standard ellipse area $\left(0.75 \%{ }^{2}\right)$ followed by SA and LMSA (0.86 and $2.55 \%{ }^{2}$, respectively). Differences between species were also highlighted with the absence of overlap in the $40 \%$ credibility intervals between GHA and SA corrected standard ellipse areas as well as between SA and LMSA, and only $0.14 \%{ }^{2}$ overlap between GHA and LMSA corrected standard ellipse areas.
Table 3. Mean values $( \pm \mathrm{SD})$ or ranges for fatty acid composition of stomach oil triacylglycerol fractions (detected at $>0.5 \%$ of total fatty acids) for the 3 species (grey-headed [GHA], light-mantled sooty [LMSA] and sooty [SA] albatrosses). SFA: saturated fatty acids; MUFA: monounsaturated fatty acids; PUFA: polyunsaturated fatty acids

\begin{tabular}{|lrrc|}
\hline & GHA $(\mathrm{n}=9)$ & LMSA $(\mathrm{n}=9)$ & SA $(\mathrm{n}=2)$ \\
\hline $14: 0$ & $5.01 \pm 1.70$ & $4.96 \pm 2.00$ & $2.71-3.78$ \\
$16: 0$ & $14.72 \pm 2.81$ & $13.53 \pm 2.96$ & $10.87-15.73$ \\
$18: 0$ & $1.87 \pm 0.43$ & $1.86 \pm 0.67$ & $1.57-3.44$ \\
$16: 1(\mathrm{n}-9)$ & $0.23 \pm 0.16$ & $0.52 \pm 0.22$ & $1.13-0.79$ \\
$16: 1(\mathrm{n}-7)$ & $6.88 \pm 0.79$ & $7.45 \pm 1.67$ & $5.08-5.34$ \\
$18: 1(\mathrm{n}-9)$ & $20.31 \pm 3.77$ & $22.36 \pm 2.95$ & $25.77-28.32$ \\
$18: 1(\mathrm{n}-7)$ & $6.28 \pm 1.51$ & $7.04 \pm 1.17$ & $5.57-4.85$ \\
$18: 1(\mathrm{n}-5)$ & $0.62 \pm 0.19$ & $0.59 \pm 0.15$ & $0.60-0.50$ \\
$20: 1(\mathrm{n}-11)$ & $0.42 \pm 0.21$ & $0.71 \pm 0.53$ & $0.53-0.53$ \\
$20: 1(\mathrm{n}-9)$ & $7.17 \pm 2.42$ & $7.26 \pm 2.73$ & $7.07-8.93$ \\
$20: 1(\mathrm{n}-7)$ & $0.64 \pm 0.13$ & $0.70 \pm 0.18$ & $0.45-0.67$ \\
$22: 1(\mathrm{n}-11)$ & $2.21 \pm 1.04$ & $2.51 \pm 1.37$ & $1.33-3.48$ \\
$22: 1(\mathrm{n}-9)$ & $1.55 \pm 0.43$ & $1.55 \pm 0.55$ & $0.99-2.06$ \\
$24: 1(\mathrm{n}-9)$ & $0.85 \pm 0.28$ & $0.91 \pm 0.40$ & $0.66-1.46$ \\
$18: 2(\mathrm{n}-6)$ & $1.44 \pm 0.30$ & $1.42 \pm 0.35$ & $1.18-0.79$ \\
$18: 4(\mathrm{n}-3)$ & $0.88 \pm 0.21$ & $0.65 \pm 0.16$ & $0.19-0.26$ \\
$20: 4(\mathrm{n}-6)$ & $0.61 \pm 0.14$ & $0.64 \pm 0.11$ & $1.06-0.59$ \\
$20: 4(\mathrm{n}-3)$ & $0.72 \pm 0.18$ & $0.74 \pm 0.09$ & $0.76-0.50$ \\
$20: 5(\mathrm{n}-3)$ & $10.36 \pm 2.27$ & $7.86 \pm 1.52$ & $10.81-3.66$ \\
$22: 5(\mathrm{n}-3)$ & $1.04 \pm 0.30$ & $1.34 \pm 0.68$ & $1.44-0.68$ \\
$22: 6(\mathrm{n}-3)$ & $9.99 \pm 1.88$ & $8.99 \pm 1.60$ & $15.78-7.19$ \\
Others & $6.17 \pm 0.90$ & $6.41 \pm 0.46$ & $4.44-6.43$ \\
SFA & $23.36 \pm 4.98$ & $22.10 \pm 5.59$ & $16.11-25.29$ \\
MUFA & $47.97 \pm 6.58$ & $52.45 \pm 7.62$ & $49.57-57.58$ \\
PUFA & $28.67 \pm 4.07$ & $25.45 \pm 3.37$ & $34.32-17.13$ \\
\hline & & & \\
\hline
\end{tabular}

Feather isotopic signatures of both $\delta^{13} \mathrm{C}$ and $\delta^{15} \mathrm{~N}$ showed that SA is segregated from GHA and LMSA $\left(\delta^{13} \mathrm{C}\right.$ : ANOVA $F=35.7, \mathrm{p}=<0.001, \mathrm{SA}>\mathrm{GHA}=$ LMSA; $\delta^{15} \mathrm{~N}$ : Wald test $=31.3, \mathrm{p}<0.001, \mathrm{SA}>$ LMSA > GHA; Table 4, Fig. $5 \mathrm{~B}) . \delta^{15} \mathrm{~N}$ and $\delta^{13} \mathrm{C}$ values were positively linearly correlated for LMSA (Pearson's correlation, $r=0.908, \mathrm{p}<0.001$ ) and SA (Pear-

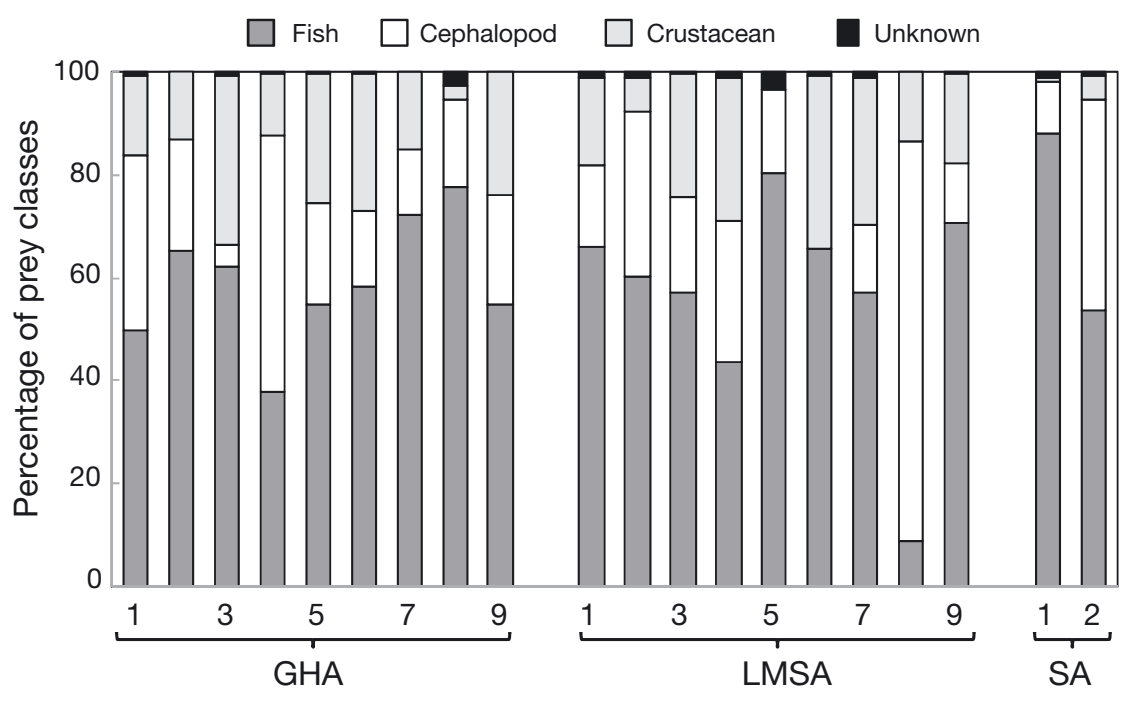

Fig. 4. Model estimates of the contribution of broad prey classes to the fatty acid fraction of stomach oil triacylglycerols for the 3 albatross species (grey-headed [GHA], lightmantled sooty [LMSA] and sooty [SA] albatrosses) 
Table 4. Stable carbon and nitrogen isotope values of whole blood and body feathers of grey-headed (GHA), light-mantled sooty (LMSA) and sooty (SA) albatrosses from Marion Island. ${ }^{* * *}$ indicates a significant difference of $\mathrm{p}<0.001$ between the 3 species. Trophic niche width (TNW), and between-individual (BIC) and within-individual (WIC) components were calculated using generalized linear mixed models. Values are mean $\pm \mathrm{SD}$

\begin{tabular}{|c|c|c|c|c|c|c|c|c|c|c|c|c|}
\hline & \multirow[t]{2}{*}{ Species } & \multirow[t]{2}{*}{$\mathrm{n}$} & \multirow[t]{2}{*}{$\delta^{13} \mathrm{C}$} & \multirow[t]{2}{*}{$\delta^{15} \mathrm{~N}$} & \multirow{2}{*}{\multicolumn{2}{|c|}{$\begin{array}{c}\text { TNW } \\
\delta^{13} \mathrm{C}^{15} \delta^{15}\end{array}$}} & \multicolumn{2}{|c|}{ WIC } & \multicolumn{2}{|c|}{ BIC } & \multicolumn{2}{|c|}{ WIC/TNW } \\
\hline & & & & & & & $\delta^{13} \mathrm{C}$ & $\delta^{15} \mathrm{~N}$ & $\delta^{13} \mathrm{C}$ & $\delta^{15} \mathrm{~N}$ & $\delta^{13} \mathrm{C}$ & $\delta^{15} \mathrm{~N}$ \\
\hline \multirow[t]{3}{*}{ Blood } & GHA & 24 & $-22.72 \pm 0.50$ & $10.80 \pm 0.52$ & & & & & & & & \\
\hline & LMSA & 8 & $-23.08 \pm 0.84$ & $11.64 \pm 0.98$ & & & & & & & & \\
\hline & SA & 15 & $-21.00 \pm 0.81$ & $\underset{* * *}{12.46 \pm 0.53}$ & & & & & & & & \\
\hline \multirow[t]{3}{*}{ Feathers } & GHA & 24 & $-19.33 \pm 1.12$ & $11.64 \pm 0.80$ & 1.86 & 1.92 & 0.81 & 1.70 & 1.05 & 0.22 & 0.44 & 0.89 \\
\hline & LMSA & 8 & $-19.50 \pm 1.51$ & $12.46 \pm 0.79$ & 4.19 & 2.41 & 2.59 & 2.41 & 1.60 & $<0.01$ & 0.62 & 1.00 \\
\hline & SA & 15 & $-17.96 \pm 0.93$ & $\underset{* * *}{14.00 \pm 0.63}$ & 1.53 & 0.75 & 0.88 & 0.47 & 0.65 & 0.28 & 0.58 & 0.63 \\
\hline
\end{tabular}

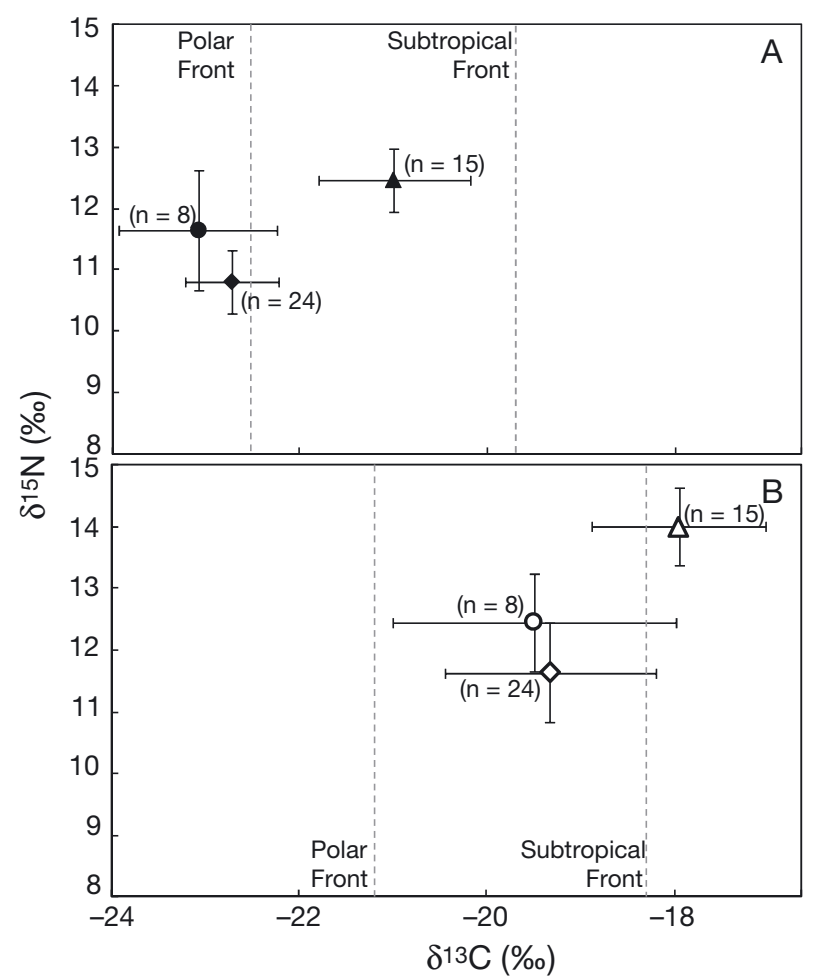

Fig. 5. Stable carbon and nitrogen values of blood ( $A_{;}$closed symbols) and feathers ( $\mathrm{B}$; open symbols) of adult light-mantled sooty $(\bullet, \bigcirc)$, grey-headed $(\bullet, \diamond)$ and sooty $(\boldsymbol{\Delta}, \Delta)$ albatrosses. Isotopic values referring to the position of the Polar and Subtropical fronts follow Cherel \& Hobson (2007) and Jaeger et al. (2010b)

son's correlation, $\mathrm{r}=0.846, \mathrm{p}<0.001)$ feathers, but not for GHA feathers (Pearson's correlation, $\mathrm{r}=$ -0.083, $p=0.422$ ). Feathers from the 3 species showed high variability in both their $\delta^{13} \mathrm{C}$ and $\delta^{15} \mathrm{~N}$ values, with the isotopic niche being the widest for LMSA and GHA samples followed by SA (Table 4). Corrected standard ellipse areas and convex hull areas reflected these results, with GHA and LMSA indices being 2 to 3 times the size of SA (centred and rescaled data: corrected standard ellipse areas $2.28 \%{ }^{2}, \quad 1.64 \%^{2}, 0.69 \%{ }^{2}$ and convex hull areas $9.69 \%{ }^{2}, 5.27 \%{ }^{2}, 2.74 \%{ }^{2}$ for GHA, LMSA and SA, respectively; Fig. 6B). The isotopic overlap between GHA and SA was almost non-existent $\left(<0.0001 \%{ }^{2}\right)$ for the $40 \%$ credibility interval. On the contrary, half of the LMSA area was shared with the GHA area and $<10 \%$ of the areas were shared between LMSA and SA (Fig. 6B). Finally, intra-individual variation was higher than inter-individual variation in $\delta^{13} \mathrm{C}$ for LMSA and SA. For $\delta^{15} \mathrm{~N}$, intra-individual variation was higher than inter-individual variation for all 3 species (Table 4).

\section{DISCUSSION}

This study is one of the first investigations combining 3 complementary methods - stomach content, lipid and stable isotope analyses - to look at the diet and feeding ecology of seabirds (Karnovsky et al. 2008, Connan et al. 2010b). The 3 sympatric species of medium-size albatrosses from Marion Island exhibited complex spatial and trophic patterns with varying degrees of overlap among the species during the chick-rearing and moulting seasons.

\section{Chick-rearing period}

During the breeding season, $\delta^{13} \mathrm{C}$ blood isotopic signatures together with the well-known latitudinal $\delta^{13} \mathrm{C}$ gradient within the Southern Ocean (e.g. Cherel \& Hobson 2007, Jaeger et al. 2010b) showed that GHA and LMSA foraged in Antarctic waters and/or 

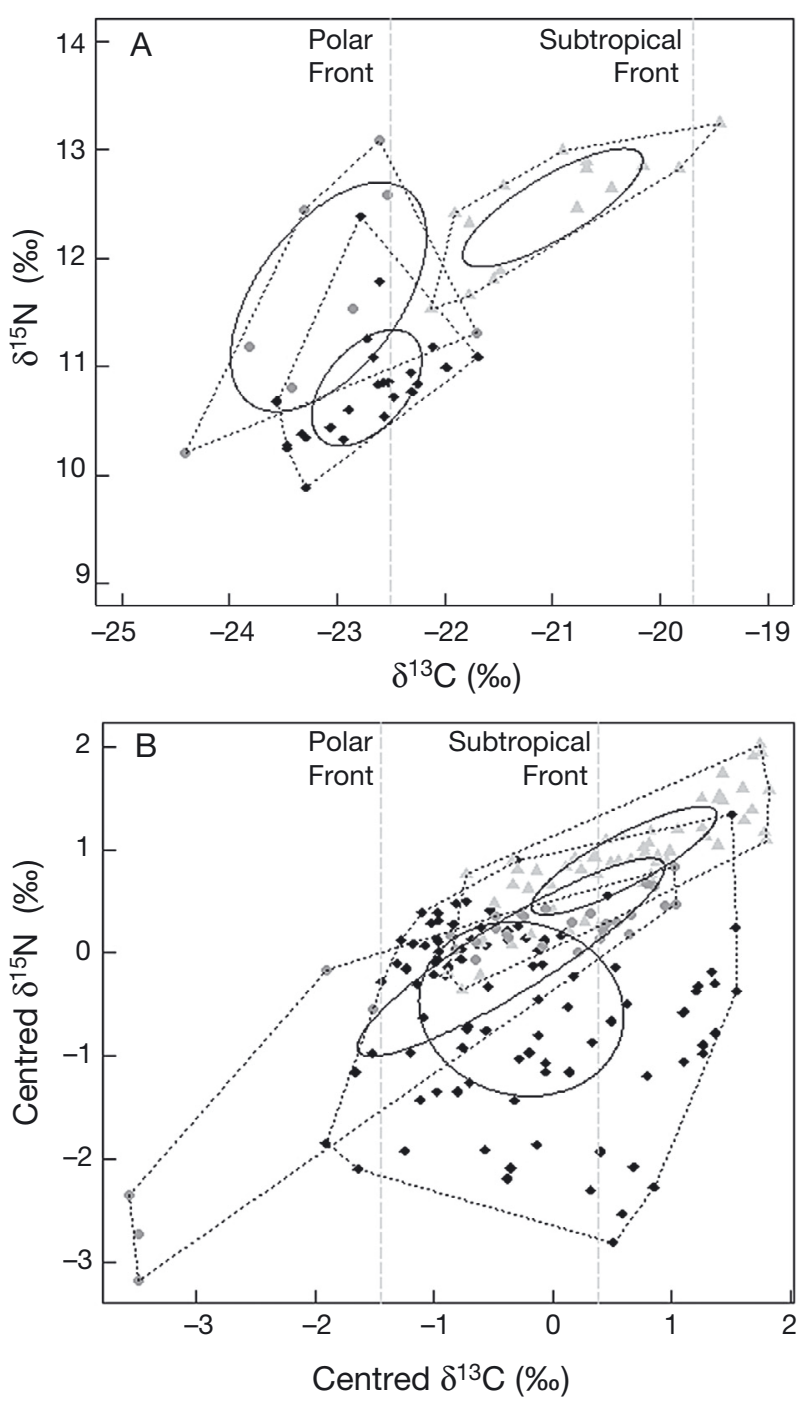

Fig. 6. Stable carbon and nitrogen values of blood (A) and individual feathers (centred and rescaled data; B) of adult grey-headed (black), light-mantled sooty (grey) and sooty (light grey) albatrosses. Standard ellipse areas (solid lines) and convex hull areas (dashed lines) were estimated using Stable Isotope Bayesian Ellipses in R (Jackson et al. 2011). Isotopic values referring to the position of the Polar and Subtropical fronts follow Cherel \& Hobson (2007) and Jaeger et al. (2010b)

in the proximity of the Polar Front, while SA foraged mainly in subantarctic waters (Table 4, Fig. 5A \& 6A). To our knowledge, no tracking data of LMSA and SA from Marion Island have been published, but tracked GHA forage mainly to the southwest of the island during chick rearing ( $\mathrm{Nel}$ et al. 2001). This pattern was also supported by dietary analysis, with the identification of some high-Antarctic species only in GHA and LMSA food samples: the Antarctic krill Euphausia superba and the squid Psychroteuthis glacialis. Noticeably, food samples represent chick food and not the food of the adults when they feed for themselves. Hence, it is likely that both GHA and LMSA adults include a higher proportion of Antarctic prey in their diet.

Interestingly, the identification of Phosichthys argenteus in GHA samples (Nel et al. 2001, Richoux et al. 2010, this study) suggests that from time to time, foraging trips are also undertaken in subtropical waters. $P$. argenteus has never been caught south of $49^{\circ} \mathrm{S}$ (Froese \& Pauly 2012), and is regularly identified in the diet of the yellow-nosed albatross Thalassarche chlororhynchos, which forages in subtropical waters (Pinaud et al. 2005). In the same way, the presence of beaks from squid with different biogeographic affinities in food samples suggested that the foraging range of SA is not restricted to subantarctic waters but also includes northern waters of the subtropical zone. For example, Histioteuthis miranda and Ancistrocheirus lesueuri were identified in 30 and $20 \%$ of the SA contents, respectively, and are mainly found north of the Subtropical Front (Xavier \& Cherel 2009).

Blood $\delta^{15} \mathrm{~N}$ values revealed that SA and LMSA were feeding at a slightly higher trophic level than GHA during chick rearing (Table 4, Fig. 5A \& 6A), which is in agreement with a higher proportion of Antarctic krill, a lower trophic level prey in the food samples of GHA. Moreover, $\delta^{15} \mathrm{~N}$ values are overall higher in squid than in fish, from 10.0 to $10.9 \%$ and from 7.3 to $10.2 \%$, respectively (Cherel et al. 2008, 2010), and squid formed higher percentages by mass in LMSA and SA than in GHA food samples. Interestingly, diacylglycerol ethers, which have been suggested as originating from squid species (Connan et al. 2007), were identified in 1 out of 2 SA oils, 4 out of 9 LMSA oils and only 1 out of 9 GHA oils.

Triacyglycerol origins were more variable between individuals than between the 3 species of albatrosses and even for the 2 Phoebetria species, most of the triacyglycerols seemed to originate from fish species. Surprisingly, the icefish Champsocephalus gunnari was identified as one of the species from which the oils originated. This species has been identified in GHA stomach content from South Georgia (Cherel \& Klages 1998); however it does not seem to occur in the vicinity of the Prince Edward Islands (Kock \& Everson 1997). This result probably reflects the fact that, despite gathering as many potential prey species as possible, some were absent from the database. Hence, instead of feeding on icefish, the albatrosses could possibly have foraged on a prey species or a mix of prey showing similarities in fatty acid 
triacyglycerol composition with that of icefish. The presence of oils derived from Antarctic krill Euphausia superba in all 3 species suggests that SA sometimes also feed in Antarctic waters. Indeed, previous dietary investigations identified Antarctic krill in a few SA food samples (Ridoux 1994, Cooper \& Klages 1995).

In brief, the combination of dietary techniques showed that complex spatial and trophic segregations exist between the 3 albatross species. When feeding for themselves (blood isotopic signatures), adult SA showed a clear spatial segregation with the 2 other species. When bringing back food for their chicks (stomach contents), trophic segregation became obvious between GHA, feeding on a mix of fish and squids, and the 2 Phoebetria species, specializing mostly on squids.

\section{Interbreeding (moulting) period}

Due to the high energetic cost of growing new feathers, many bird species dissociate moulting and breeding, at least at the individual level. Some albatross species even skip a breeding season when their moult has not been completed (Rohwer et al. 2011).

When taking into account the latitudinal $\delta^{13} \mathrm{C}$ gradient from the Southern Ocean (Jaeger et al. 2010b), feather $\delta^{13} \mathrm{C}$ values showed that, when not breeding, SA were spatially segregated from LMSA and GHA by foraging mostly in northern areas (northern subantarctic and subtropical waters), while the 2 other species were mainly concentrated in subantarctic waters. In addition, feather $\delta^{15} \mathrm{~N}$ isotope signatures showed that the albatross species foraged at different trophic levels (Table 4, Figs. 5B \& 6B).

During moult, GHA mainly foraged in subantarctic waters $(>70 \%$ of feathers), where they preyed at several trophic levels $\left(7.9 \%<\delta^{15} \mathrm{~N}_{\mathrm{GHA}}<14.7 \%\right.$ o). $\delta^{15} \mathrm{~N}$ values suggested that GHA would have preyed on fish and squid (Cherel et al. 2008, 2010), as well as lower trophic level prey such as crustaceans or more probably jellyfish and/or salps. Black-browed albatrosses Thalassarche melanophris have been documented feeding on jellyfish umbrellas (Suazo 2008), and, using stomach temperature recorders, Catry et al. (2004) showed that GHA foraged on rapidly digested prey (e.g. salps and jellyfish). Taken together, these studies suggest that the role of gelatinous species has been overlooked in the diet of albatrosses.

Moulting SA foraged in northern waters (mainly in the subtropical zone) rather than the subantarctic waters used during the breeding season. Individual feather data showed that all birds foraged at the same trophic level (low BIC), and that each bird was faithful to that trophic level throughout moulting (low

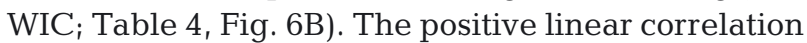
between $\delta^{15} \mathrm{~N}$ and $\delta^{13} \mathrm{C}$ values detected in SA (and LMSA) feathers has been found in several other studies (e.g. birds: Phillips et al. 2009, Jaeger et al. 2010a,b; squids: Cherel \& Hobson 2005), suggesting not only that $\delta^{13} \mathrm{C}$ decreases with latitude, but also that the $\delta^{15} \mathrm{~N}$ baseline exhibits latitudinal changes within the Southern Ocean (Jaeger et al. 2010a).

In contrast, individual feather analysis of LMSA showed that 3 feathers had been moulted in highAntarctic waters $\left(\delta^{13} \mathrm{C}<-24 \%\right), 2$ in proximity to the Polar Front $\left(\delta^{13} \mathrm{C} \sim-21.5 \%\right.$ ) and the others in the subantarctic area in the vicinity of the Subtropical Front $\left(-20.3 \%<\delta^{13} \mathrm{C}_{\mathrm{LMSA}}<-17.3 \%\right)$. When moulting in subantarctic waters, LMSA fed on fish and squids $\left(12.4 \%<\delta^{15} \mathrm{~N}_{\mathrm{LMSA}}<13.9 \%\right)$, while in high-Antarctic waters they were likely to prey on Antarctic krill as shown by their low $\delta^{15} \mathrm{~N}$ signatures $\left(7.3 \%<\delta^{15} \mathrm{~N}_{\mathrm{LMSA}}\right.$ $<8.6 \%$ ), which were similar to that of the euphausiid feeding Adélie penguin Pygoscelis adeliae $\left(\delta^{15} \mathrm{~N}=\right.$ $7.9 \%$; Cherel 2008).

\section{Temporal and spatial variability in the diet and feeding ecology of the three albatross species}

SA generally breeds on more northerly islands than GHA and LMSA. Hence, while GHA and LMSA breeds in sympatry on several islands all around the Southern Ocean, the 3 species occur together in significant numbers in only 2 archipelagos of the southern Indian Ocean, namely the Prince Edward Islands and the Crozet Islands; the former locality is the only place where they are easily accessible for scientific investigations. There, as elsewhere, stomach content studies have been far more numerous than analyses of stomach oils or stable isotopes to study their food and feeding ecology (see Table S2 in the Supplement at www.int-res.com/articles/suppl/m497p259 _supp.pdf), and the only tracking information available to date on GHA is from Marion Island (e.g. Nel et al. 2001).

Previous analyses of stomach contents have highlighted diet differences between populations for the 3 albatrosses, reflecting prey availability around the nesting areas (references in the supplement, review in Cherel \& Klages 1998). For example, GHA and LMSA from South Georgia contained far more crustaceans (mainly Antarctic krill Euphausia superba; Thomas 1982, Catry et al. 2004) than at any other 
localities, reflecting the abundance of Antarctic krill in the waters surrounding the island. At Marion and Crozet islands, a synthesis of prey biogeography showed that GHA, LMSA and SA are partially spatially segregated during chick rearing, with SA foraging in warmer, more northerly waters than LMSA and GHA, with a substantial overlap in subantarctic waters (Berruti \& Harcus 1978, Ridoux 1994, Cooper \& Klages 1995, Richoux et al. 2010, this study).

Previously, 12 GHA oils were collected in 2006 on Marion Island and 1 from an LMSA chick on Campbell Island, but none from SA (Warham et al. 1976, Richoux et al. 2010). The distinct fatty acid compositions of GHA between the samples collected in 2006 and 2009 might be explained by (1) the protocols used (Richoux et al. [2010] analysed total fatty acid compositions, i.e. mix of lipid classes from different prey origins) and/or (2) different prey ingested by the birds. The LMSA oil collected on Campbell Island showed strong similarities to those collected in our study, with triacylglycerols representing $>80 \%$ of lipid classes and similar fatty acid compositions. Unfortunately, the precision given in Warham et al. (1976; group of fatty acids such as 20:1, 22:1) precludes deeper comparisons of prey origins.

GHA adult blood $\delta^{13} \mathrm{C}$ values (Marion Island; Richoux et al. 2010, this study) together with chick feather $\delta^{13} \mathrm{C}$ values (Crozet Islands; Jaeger et al. 2010a) indicate foraging in cold southern waters of the southern Indian Ocean during the chick-rearing period. Adult blood $\delta^{13} \mathrm{C}$ values were higher for birds from South Georgia, but are in agreement with birds foraging mostly to the north of the island during early chick rearing (Phillips et al. 2004, Anderson et al. 2009, Phillips et al. 2011). No adult blood $\delta^{13} \mathrm{C}$ and $\delta^{15} \mathrm{~N}$ values of LMSA and SA are available, but chick feather $\delta^{13} \mathrm{C}$ values from the Crozet Islands again show different isotopic niches for the 2 species, with SA foraging further north and at a higher trophic position than LMSA during the chick-rearing period (Jaeger et al. 2010a).

During the interbreeding (moulting) period, feather $\delta^{13} \mathrm{C}$ values of adult GHA were remarkably similar in all localities and years so far investigated, with birds foraging primarily in subantarctic waters (Anderson et al. 2009, Phillips et al. 2009, Cherel et al. 2013, this study). Results are more variable for the 2 Phoebetria albatrosses. Depending on localities and years, feather $\delta^{13} \mathrm{C}$ values of LMSA ranged from -19.5 to $-21.2 \%$, with very large variances (Jaeger et al. 2010a, Cherel et al. 2013, this study), except at South Georgia (Phillips et al. 2009). The low standard deviation at the latter locality is likely the result of meas- uring stable isotopes on a pool of body feathers instead of a single feather, thus blurring any intraindividual variation (Jaeger et al. 2010a). Otherwise, the interbreeding strategy of LMSA is consistent among colonies, with birds moulting from highAntarctic to subtropical waters with a focus in the subantarctic zone. Finally, the feather $\delta^{13} \mathrm{C}$ values of SA depicted 2 moulting strategies, with birds from Marion, Crozet and Amsterdam islands moulting mostly north of the Subtropical Front, whereas birds from Gough Island moult mainly in subantarctic waters (Jaeger et al. 2010a, Cherel et al. 2013, this study).

In summary, by combining dietary techniques that integrate the food and feeding habits over days, weeks and months, the present work highlights a complex pattern of spatial and trophic segregations among the medium-size albatross species that breed biennially on Marion Island (only island with an easy access to the 3 sympatric species). The next step should be to track individual birds using satellite tags and geolocation loggers during the breeding and interbreeding periods, respectively, to complete the picture. Both biologging and the stable isotope method can also help to investigate the foraging ecology of juveniles and immature birds, which remains poorly known.

Acknowledgements. The authors thank P. G. Ryan, M. DaviesColeman, E. L. Allan, A. L. Jackson, M. G. W. Jones, N. T. W. Klages, J. Kolasinski, P. Pistorius, N. Richoux, S. Sunassee, C. Tambling, B. Dyer and L. Clokie for their valuable advice at different stages of this study. The manuscript benefited from the constructive comments of 4 anonymous reviewers and the Editor. We acknowledge the Fatty Acid Facility at Rhodes University funded through the National Research Foundation and Rhodes University. Isotope samples were analyzed by I. Newton at the Stable Light Isotope Laboratory of the University of Cape Town under the supervision of J. Lanham. Funding and logistical support was provided by the Department of Environmental Affairs and Tourism through the South African National Antarctic Program and administered by the National Research Foundation. M.C. acknowledges funding from the University of Cape Town's Marine Research Institute. This work is based on research supported by the South African Research Chairs Initiative of the Department of Science and Technology and the National Research Foundation. This work was undertaken under an ethics permit granted by Rhodes University.

\section{LITERATURE CITED}

Allan EL, Ambrose ST, Richoux NB, Froneman PW (2010) Determining spatial changes in the diet of nearshore suspension-feeders along the South African coastline: stable isotope and fatty acid signatures. Estuar Coast Shelf Sci $87: 463-471$ 
Anderson ORJ, Phillips RA, McDonald RA, Shore RF, McGill RAR, Bearhop S (2009) Influence of trophic position and foraging range on mercury levels within a seabird community. Mar Ecol Prog Ser 375:277-288

Berruti A, Harcus T (1978) Cephalopod prey of the sooty albatrosses Phoebetria fusca and P. palpebrata at Marion Island. S Afr J Antarct Res 8:99-103

> Bolnick DI, Yang LH, Fordyce JA, Davis JM, Svanbäck R (2002) Measuring individual-level resource specialization. Ecology 83:2936-2941

Catry P, Phillips RA, Phalan B, Silk JRD, Croxall JP (2004) Foraging strategies of grey-headed albatrosses Thalassarche chrysostoma: integration of movements, activity and feeding events. Mar Ecol Prog Ser 280:261-273

> Cherel Y (2008) Isotopic niches of emperor and Adélie penguins in Adélie Land, Antarctica. Mar Biol 154:813-821

Cherel Y, Hobson KA (2005) Stable isotopes, beaks and predators: a new tool to study ecology of cephalopods, including giant and colossal squids. Proc R Soc Lond B Biol Sci 272:1601-1607

Cherel Y, Hobson KA (2007) Geographical variation in carbon stable isotope signatures of marine predators: a tool to investigate their foraging areas in the Southern Ocean. Mar Ecol Prog Ser 329:281-287

Cherel Y, Klages N (1998) A review of the food of albatrosses. In: Robertson G, Gales R (eds) The albatross: biology and conservation. Surrey Beatty \& Sons, Chipping Norton, p 113-136

Cherel Y, Hobson KA, Hassani S (2005) Isotopic discrimination between food and blood and feathers of captive penguins: implications for dietary studies in the wild. Physiol Biochem Zool 78:106-115

> Cherel Y, Ducatez S, Fontaine C, Richard P, Guinet C (2008) Stable isotopes reveal the trophic position and mesopelagic fish diet of female southern elephant seals breeding on the Kerguelen Islands. Mar Ecol Prog Ser 370: 239-247

> Cherel Y, Fontaine C, Richard P, Labat JP (2010) Isotopic niches and trophic levels of myctophid fishes and their predators in the Southern Ocean. Limnol Oceanogr 55: 324-332

> Cherel Y, Jaeger A, Alderman R, Jaquemet S and others (2013) A comprehensive isotopic investigation of habitat preferences in nonbreeeding albatrosses from the Southern Ocean. Ecography 36:277-286

> Connan M, Mayzaud P, Boutoute M, Weimerskirch H, Cherel Y (2005) Lipid composition of stomach oil in a procellariiform seabird Puffinus tenuirostris: implications for food web studies. Mar Ecol Prog Ser 290:277-290

Connan M, Cherel Y, Mayzaud P (2007) Lipids from stomach oil of procellariiform seabirds document the importance of myctophid fish in the Southern Ocean. Limnol Oceanogr 52:2445-2455

Connan M, Mayzaud P, Duhamel G, Bonnevie BT, Cherel Y (2010a) Quantitative fatty acid signature analysis documents the diet of five myctophid fish from the Southern Ocean. Mar Biol 157:2303-2316

Connan M, Mayzaud P, Hobson KA, Weimerskirch H, Cherel Y (2010b) Food and feeding ecology of the Tasmanian short-tailed shearwater (Puffinus tenuirostris, Temminck): insights from three complementary methods. J Oceanogr 3:19-32

Connan M, Kelly CMR, McQuaid CD, Bonnevie BT, Barker NP (2011) Morphological versus molecular identification of Sooty and Light-mantled albatross chicks. Polar Biol
34:791-798

Cooper J, Klages NTW (1995) The diets and dietary segregation of sooty albatrosses (Phoebetria spp.) at subantarctic Marion Island. Antarct Sci 7:15-23

Croxall JP, Reid K, Prince PA (1999) Diet, provisioning and productivity responses of marine predators to differences in availability of Antarctic krill. Mar Ecol Prog Ser 177: 115-131

Froese R, Pauly D (eds) (2012) FishBase. www.fishbase.org, accessed 10 Oct 2012

Hammer Ø, Harper DAT, Ryan PD (2001) PAST: paleontological statistics software package for education and data analysis. Palaeontol Electronica 4(1):art4

Harrison P (1983) Seabirds: an identification guide. Croom Helm, Beckenham

Hobson KA, Clark RG (1992) Assessing avian diets using stable isotopes I: turnover of ${ }^{13} \mathrm{C}$ in tissues. Condor 94 : 181-188

Hobson KA, Gibbs HL, Gloutney ML (1997) Preservation of blood and tissue samples for stable-carbon and stablenitrogen isotope analysis. Can J Zool 75:1720-1723

Hockey PAR, Dean WRJ, Ryan PG (2005) Roberts birds of Southern Africa, 7th edn. The Trustees of the John Voelcker Bird Book Fund, Cape Town

> Iverson SJ, Field C, Bowen WD, Blanchard W (2004) Quantitative fatty acid signature analysis: a new method of estimating predator diets. Ecol Monogr 74:211-235

> Jackson AL, Inger R, Parnell AC, Bearhop S (2011) Comparing isotopic niche widths among and within communities: SIBER - Stable Isotope Bayesian Ellipses in R. J Anim Ecol 80:595-602

> Jaeger A, Connan M, Richard P, Cherel Y (2010a) Use of stable isotopes to quantify seasonal changes of trophic niche and levels of population and individual specialisation in seabirds. Mar Ecol Prog Ser 401:269-277

> Jaeger A, Lecomte VJ, Weimerskirch H, Richard P, Cherel Y (2010b) Seabird satellite tracking validates the use of latitudinal isoscapes to depict predators' foraging areas in the Southern Ocean. Rapid Commun Mass Spectrom 24:3456-3460

> Karnovsky NJ, Hobson KA, Iverson SJ, Hunt GL (2008) Seasonal changes in diets of seabirds in the North Water Polynya: a multiple-indicator approach. Mar Ecol Prog Ser 357:291-299

> Karnovsky NJ, Hobson KA, Iverson SJ (2012) From lavage to lipids: estimating diets of seabirds. Mar Ecol Prog Ser 451:263-284

- Kock KH, Everson I (1997) Biology and ecology of mackerel icefish, Champsocephalus gunnari: an Antarctic fish lacking hemoglogin. Comp Biochem Physiol A 118: 1067-1077

Lutjeharms JRE, Ansorge IJ (2008) Oceanographic settings of the Prince Edward Islands. In: Chown SN, Froneman PW (eds) The Prince Edwards Archipelago: land-sea interactions in a changing ecosystem. Sun Media, Stellenbosch, p 17-38

Mizutani H, Fukuda M, Kabaya Y, Wada E (1990) Carbon isotope ratio of feathers reveals feeding behavior of cormorants. Auk 107:400-403

Nel DC, Lutjeharms JRE, Pakhomov EA, Ansorge IJ, Ryan PG, Klages NTW (2001) Exploitation of mesoscale oceanographic features by grey-headed albatross Thalassarche chrysostoma in the southern Indian Ocean. Mar Ecol Prog Ser 217:15-26

Park YH, Gambéroni L, Charriaud E (1993) Frontal struc- 
ture, water masses, and circulation in the Crozet Basin. J Geophys Res 98:12361-12385

Phillips RA, Silk JRD, Phalan B, Catry P, Croxall JP (2004) Seasonal sexual segregation in two Thalassarche albatross species: Competitive exclusion, reproductive role specialization or foraging niche divergence? Proc Soc Lond B Biol Sci 271:1283-1291

Phillips RA, Bearhop S, McGill RAR, Dawson DA (2009) Stable isotopes reveal individual variation in migration strategies and habitat preferences in a suite of seabirds during the nonbreeding period. Oecologia 160:795-806

Phillips RA, McGill RAR, Dawson DA, Bearhop S (2011) Sexual segregation in distribution, diet and trophic level of seabirds: insights from stable isotope analysis. Mar Biol 158:2199-2208

Pinaud D, Cherel Y, Weimerskirch H (2005) Effect of environmental variability on habitat selection, diet, provisioning behaviour and chick growth in yellow-nosed albatrosses. Mar Ecol Prog Ser 298:295-304

R Development Core Team (2009) R: a language and environment for statistical computing. R Foundation for Statistical Computing, Vienna, available at www.r-project.org

Richoux NB, Jaquemet S, Bonnevie BT, Cherel Y, McQuaid CD (2010) Trophic ecology of Grey-headed albatrosses from Marion Island, Southern Ocean: insights from stomach contents and diet tracers. Mar Biol 157:1755-1766

Ridoux V (1994) The diets and dietary segregation of seabirds at the sub-Antarctic Crozet Islands. Mar Ornithol 22:1-192

Rohwer S, Viggiano A, Marzluff JM (2011) Reciprocal tradeoffs between molt and breeding in albatrosses. Condor 113:61-70

Editorial responsibility: Jacob González-Solís, Barcelona, Spain
Ryan PG, Bester MN (2008) Pelagic predators. In: Chown SL, Froneman PW (eds) The Prince Edward Islands: land-sea interactions in a changing ecosystem. Sun Media, Stellenbosch, p 121-164

Ryan PG, Jones MGW, Dyer BM, Upfold L, Crawford RJM (2009) Recent population estimates and trends in numbers of albatrosses and giant petrels breeding at the sub-Antarctic Prince Edward islands. Afr J Mar Sci 31: 409-417

Suazo CG (2008) Black-browed albatross foraging on jellyfish prey in the southeast Pacific coast, southern Chile. Polar Biol 31:755-757

Syväranta J, Lensu A, Marjomäki TJ, Oksanen S, Jones RI (2013) An empirical evaluation of the utility of convex hull and standard ellipse areas for assessing population niche widths from stable isotope data. PLoS ONE 8: e56094

Thomas G (1982) The food and feeding ecology of the Lightmantled albatross at South Georgia. Emu 82:92-100

Warham J (1996) The behaviour, population biology and physiology of the petrels. Academic Press, London and San Diego, CA

> Warham J, Watts R, Dainty RJ (1976) The composition, energy content and function of the stomach oils of petrels (order, Procellariiformes). J Exp Mar Biol Ecol 23:1-13

Xavier JC, Cherel Y (2009) Cephalopod beak guide for the Southern Ocean. British Antarctic Survey, Cambridge

Xavier JC, Phillips RA, Cherel Y (2011) Cephalopods in marine predator diet assessments: why identifying upper and lower beaks is important. ICES J Mar Sci 68: 1857-1864

Submitted: October 12, 2012; Accepted: October 15, 2013 Proofs received from author(s): January 10, 2014 